Book Title:

Finding God in the shadows: Stories from the battlefields of life

\section{Book Cover}

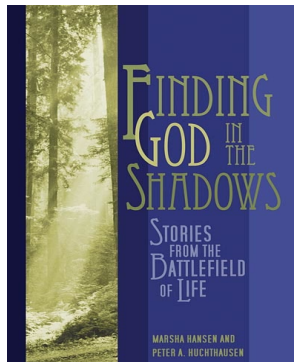

Authors:

Marsha Hansen

Peter A. Huchthausen

\section{ISBN:}

978-0-8066-5326-6

\section{Publisher:}

Augsburg Books,

Minneapolis, 2008, pp. 180, cost unknown

\section{Review Title:}

Issues of faith and war

\section{Reviewer:}

Willem J. Smith

\section{Affiliation:}

${ }^{1}$ Department of Practical

Theology, University of

Pretoria, South Africa

email:

benoryn@nhk.co.za

\section{Postal address:}

Department of Practical Theology, University of Pretoria, Lynwood Road, Hatfield 0083, South Africa

How to cite this book review: Smith, W.J., 2010, 'Issues of faith and war', HTS Teologiese Studies/Theological Studies 66(1), Art. \#991, 1 page. DOI: $10.4102 /$ hts. v66i1.991

\section{This review is available} at: http://www.hts.org.za

(c) 2010. The Authors. Licensee: OpenJournals Publishing. This work is licensed under the Creative Commons Attribution License.

\section{ISSUES OF FAITH AND WAR}

Former military officers, Marsha Hansen (former US Naval officer) and Peter Huchthausen (retired Captain in the US Navy), the writers of Finding God in the shadows: Stories from the battlefield of life, take the reader on a profound journey of faith, leading to humble encounters with the divine. War undoubtedly always casts a dark and sinister shadow over all human planning and expectations, but the stories this book tells, stories of largely unknown men and women serving in the military, become gems in the hand of the reader. The stories of these men and women reflect the hope God's people find in Him, even in the most terrifying moments of pain and horror.

Without sounding contrived or sensational, the stories present a constant source of hope. Their stories engross history and fulfill the reader with hope. In their own words:

This book is designed to help those who wish to practice what the prophet Micah taught: God's will is that we do justice, love mercy, and walk humble before our God.

Not unfamiliar to us in our own lives, we find here a portrayal of men and women who are faced by the challenge of having to make imperfect, choices in difficult and dangerous situations, while still making the right decision. They are people like us, who exhibit moral courage in the face of hardship, privation and the burden of making life and death decisions that will determine the fate of others.

The stories told in this book are all true and stem from World War II, the Vietnam War and the Cold War. The stories tell of extreme situations in desperate times. The authors' intent in telling the stories, I believe, was not to offer a theology of war, but rather to examine issues of faith and ethics through the experiences of people whose lives had been touched and changed in crises. Each story is followed by a reflection that juxtaposes the characters and their tale against Biblical events that shed light on modern realities. In so doing, the writers are not exercising some kind of Biblical theology. It simply is '... the juxtaposition of ancient and modern stories in such a way that they shed light on each other and draw out common themes of justice, love and mercy' (2008:vii). These are stories that have motivated and will continue to motivate people of faith in their struggle to be faithful to God who has called them.

By exploring the ordinary realities in which many people of the Bible had encountered and attempted to serve God, the writers create a framework for deeper contemplation about the stories they provide us with. Against a Biblical background, it matters little that the stories are primarily war accounts. What the writers offer us, is a demonstration, that regardless the circumstances, even war, for every person all of life revolves around one question: 'Will I see the image of God in others ...?' (2008:viii).

For someone who has experienced the reality of pain and loss and who is seeking to live with hope coram Deo, the stories in Finding God in the shadows, reflect the hope God offers His people, even in the most terrifying moments of pain and horror. For this reason, the book can be recommended. As the authors, quoting Bonhoeffer, said: 'For decent people everywhere ... courageous intervention, and the readiness to suffer for what is acknowledged as right, help make the loving care of God credible' (2008:178). 